Received: 17 May 2018

Accepted: 3 April 2019

Published online: 06 June 2019

\section{Cheese whey to biohydrogen and useful organic acids: A non- pathogenic microbial treatment by L. acidophilus}

\author{
Anjana Pandey ${ }^{1}$, Saumya Srivastava ${ }^{1}$, Priya Rai ${ }^{1} \&$ Mikel Duke ${ }^{2}{ }^{2}$
}

The burgeoning organic waste and continuously increasing energy demands have resulted in significant environmental pollution concerns. To address this issue, the potential of different bacteria to produce biogas/biohydrogen from organic waste can be utilized as a source of renewable energy, however these pathogenic bacteria are not safe to use without strict contact isolation. In this study the role of safe food grade lactic acid bacteria (Lactobacillus spp.) was investigated for production of biogas from cheese waste with starting hexose concentration $32 \mathrm{~g} / \mathrm{L}$. The bacterium Lactobacillus acidophilus was identified as one of the major biogas producers at optimum $\mathrm{pH}$ of 6.5. Further the optimum inoculum conditions were found to be $12.5 \%$ at inoculum age of $18 \mathrm{~h}$. During the investigation the maximum biogas production was observed to be $1665 \mathrm{~mL}$ after 72 hours of incubation at pH 6.5. The biogas production was accompanied with production of other valuable metabolites in the form of organic acids including pyruvate, propionate, acetate, lactate, formate and butyrate. Thus this research is paving way for nonpathogenic production of biohydrogen from food waste.

Exhaustion of conventional energy reserves, global warming and elevated environmental pollution have necessitated the utilization of alternative energy sources ${ }^{1,2}$. The utmost challenge today is the substitution of conventional fuels with renewable and carbon neutral energy sources. One such possibility to overcome this challenge is the use of microorganisms that are capable to produce energy from renewable sources, and in sufficient quantity to substitute energy produced by fossil fuels, without disturbing the environmental equilibrium and human food-supply system ${ }^{3-8}$.

As per FAO report ${ }^{9}$, approximately 1.3 billion tonnes of foods including fresh vegetables, fruits, meat, bakery and dairy products are wasted in the food supply chain. The quantity of wasted food discharged from different places such as food processing plants, cafeterias, restaurants and household kitchens is expected to upsurge in the coming decades owing to population and economic growth. The wasted food can be utilised, along with other combustible municipal wastes, for energy production. Despite this relatively simple means to harness energy from waste, combustion of food waste results in air pollution and loss of chemical values of organic materials. Studies have suggested that a proper food management of food waste is needed ${ }^{10}$.

Food waste with high content of carbohydrate is suitable for $\mathrm{H}_{2}$ production which is a carbon free energy carrier that can be used for clean energy production. The hydrogen $\left(\mathrm{H}_{2}\right)$ yields ranging from 0.9 to $8.35 \mathrm{~mol} \mathrm{H}_{2} / \mathrm{mol}$ hexose $^{11}$ have been observed. Numerous factors including food waste composition, pre-treatment methods and process used can affect $\mathrm{H}_{2}$ production. Hydrogen production from carbohydrate based waste has been observed to be 20 fold higher than hydrogen yield from fat and protein based food waste ${ }^{12}$.

Hydrogen is regarded as a substitute energy carrier owing to its greater energy yield $(122 \mathrm{~kJ} / \mathrm{g})$ i.e. 2.75 times higher than that of common hydrocarbon based fuels and non-polluting emissions. $\mathrm{H}_{2}$ can be produced by dark fermentation using organic wastes as starting material ${ }^{13}$.

Hydrogen gas exerts an important position due to its noncarcinogenic character resulting in cleaner and sustainable energy system. It can be produced from fossil fuels or any other source which is carbon free leading to reduce the emission of greenhouse gase ${ }^{14}$. More than $90 \%$ of hydrogen production worldwide is being executed

${ }^{1}$ Department of Biotechnology, Motilal Nehru National Institute of Technology (MNNIT) Allahabad, Prayagraj, (UP), India. ${ }^{2}$ Institute for Sustainable Industries and Liveable Cities, Victoria University, Melbourne, Australia. Correspondence and requests for materials should be addressed to A.P. (email: anjanap@mnnit.ac.in) or M.D. (email: Mikel.Duke@vu.edu.au) 
by means of fossil fuels. Several microorganisms have the enzyme hydrogenases which help to release molecular hydrogen by oxidizing hydrogen to electrons and protons. The common way to produce hydrogen biologically is microbial fermentation i.e. by decomposition of organic substrates to hydrogen and carbon dioxide ${ }^{15}$. The bacteria which are able to produce hydrogen have the capability to grow autotrophically by utilizing the hydrogen gas as an energy substrate and oxygen as a terminal electron acceptor for production of water as end product ${ }^{16}$. Variety of biological species are involved in production of hydrogen viz. cyanobacteria, fermentative and photosynthetic bacteria etc ${ }^{17}$.

The estimated yearly production of lignocellulosic biomass is nearly $2.20 \times 10^{12} \mathrm{Kg}$ (dry weight) from agriculture and forestry residuals, energy crops, aquatic plants and algae ${ }^{18}$ which have potential to produce $\mathrm{H}_{2}$ at very low costs by hydrolysis and fermentation ${ }^{19}$. Translating the energy from these wastes into valuable energy offers two concurrent benefits: the production of energy and reduction in environmental pollution. Diverse groups of anaerobic microorganisms possess the potential to break complex organic matter into three valuable energy outputs, which can be garnered proficiently: methane gas $\left(\mathrm{CH}_{4}\right)$, hydrogen gas $\left(\mathrm{H}_{2}\right)$ and electrons produced by a microbial fuel cell (MFC) $)^{6-8}$.

The different reactor conditions reported use of different bacteria capable of bioconversion of organic wastes into hydrogen and most of the seed cultures used include pathogenic strains of bacteria and required specific growth conditions. The application of food grade bacteria including Lactobacillus and Lactococcus can help in overcoming these problems by introducing non-pathogenic way of waste predisposal treatment and energy production. Hence, in this study first time the effects of different food grade bacteria on biohydrogen production have been analysed, along with the effects of different parameters such as inoculum conditions and $\mathrm{pH}$. Based on the previous reports it can be hypothesized that food grade bacteria will produce the biohydrogen comparable to that from pathogenic bacteria. The proposed hypothesis was studied by analysis of biohydrogen production from food wastes by using non-pathogenic bacteria. Different parameters such as $\mathrm{pH}$, inoculum age and size have been optimized to get the maximum biohydrogen production. Cheese whey has been used as a complex substrate for biohydrogen production by Lactobacillus acidophilus in a batch reactor of capacity 2 litres.

\section{Materials and Methods}

Seed Culture. The standard strains of Lactobacillus acidophilus (Non-pathogenic, ATCC 4356), Lactobacillus casei (Non-pathogenic, ATCC 393), Lactobacillus paracasei (Non-pathogenic, ATCC BAA52), Lactococcus lactis (Non-pathogenic, ATCC 19435) and E. coli have been used in this study. Single colony obtained from well grown plate containing M17 agar plate supplemented with 1\% dextrose was used for inoculum preparation.

Comparison of microbes for evaluation of biohydrogen production potential. All the microbes were screened for hydrogen producing capability by conducting batch experiments in triplicates under anaerobic conditions. The medium composition remains the same as mentioned above. All the experiments were conducted using polypropylene bottles (capacity $150 \mathrm{~mL}$ ) with working volume of $100 \mathrm{~mL}$. These bottles were tightly capped with butyl rubber stopper to make it air tight and the whole setup was made anaerobic by sparging of argon gas. For the collection of gas evolved during the fermentation, the set up was equipped with disposable air tight syringes. The sealed bottles were carefully placed in incubator shaker $(100 \mathrm{rpm})$ maintaining temperature at $37^{\circ} \mathrm{C}$. The gas collected was measured by water displacement method.

\section{Optimization experiments of growth conditions for hydrogen production.}

1. Initial pH: The experiments were conducted to optimize the initial medium $\mathrm{pH}$ taking five different values 5.5, 6.0, 6.5, 7.0 and 7.5 knowing the fact that optimal $\mathrm{pH}$ for dark fermentative hydrogen production mostly falls within the range of 5-8. The experiments were conducted in triplicates to minimise the manual error for $18 \mathrm{~h}$ at $37^{\circ} \mathrm{C}$. The nutrient media composition containing M17 broth supplemented with $1 \%(\mathrm{w} / \mathrm{v})$ glucose was used. An inoculum size was $10 \% \mathrm{v} / \mathrm{v}$ of total working volume.

2. Inoculum Age: To optimize the inoculum age, experiments were performed under the same experimental conditions with variation in inoculum age i.e. $10 \mathrm{~h}, 12 \mathrm{~h}, 14 \mathrm{~h}, 16 \mathrm{~h}, 18 \mathrm{~h}$ and $20 \mathrm{~h}$ keeping rest other conditions same as mentioned above at $37^{\circ} \mathrm{C}$ at optimum $\mathrm{pH}$ i.e. 6.5 .

3. Inoculum size: After the optimization of initial medium $\mathrm{pH}$ and inoculums age experiments were performed to optimize the inoculum size. All the experiment conditions were same as that of the $\mathrm{pH}$ optimization experiments except of the variation in the inoculum size taking the values as 20,15,13,12 and 10 (all in percentage $\mathrm{v} / \mathrm{v}$ ) at $37^{\circ} \mathrm{C}$. The $\mathrm{pH}$ and inoculum age were kept at optimum value i.e. 6.5 and $18 \mathrm{~h}$ respectively.

Reactor study. Experiment was carried out in the Biostat $\mathrm{A}^{+}$fermenter under batch mode. The volume of reactor vessel was $2 \mathrm{~L}$, containing $900 \mathrm{~mL}$ media (3\% cheese whey, $2.5 \mathrm{~g}$ MRS media, $2.5 \mathrm{~g}$ of M17 media, $2.5 \mathrm{~g}$ of yeast extract and anamox nutrient solution) maintaining the $\mathrm{pH}$ at 6.5 with $20 \%$ of $18 \mathrm{~h}$ grown inoculum of L. acidophilus. The conditions for this fermentation were maintained with $0 \%$ oxygen, stirring at $150 \mathrm{rpm}$ and temperature at $37^{\circ} \mathrm{C}$. The gas produced during the experiments was collected by water displacement method and samples were withdrawn at different time for metabolite analysis.

Analytical methods. The gaseous products $\left(\mathrm{CO}_{2}\right.$ and $\left.\mathrm{H}_{2}\right)$ evolved from fermentation experiments were analysed by Drager's tube and gas chromatograph (Agilent $7890 \mathrm{~A}$ ) having a thermo conductivity detector and capillary column (HP-PLOT/Q). Nitrogen gas served as carrier and pure hydrogen served as standard. The oven temperature was $90^{\circ} \mathrm{C}$ and temperature of detector and injector was $100^{\circ} \mathrm{C}$ and $70^{\circ} \mathrm{C}$ respectively. 


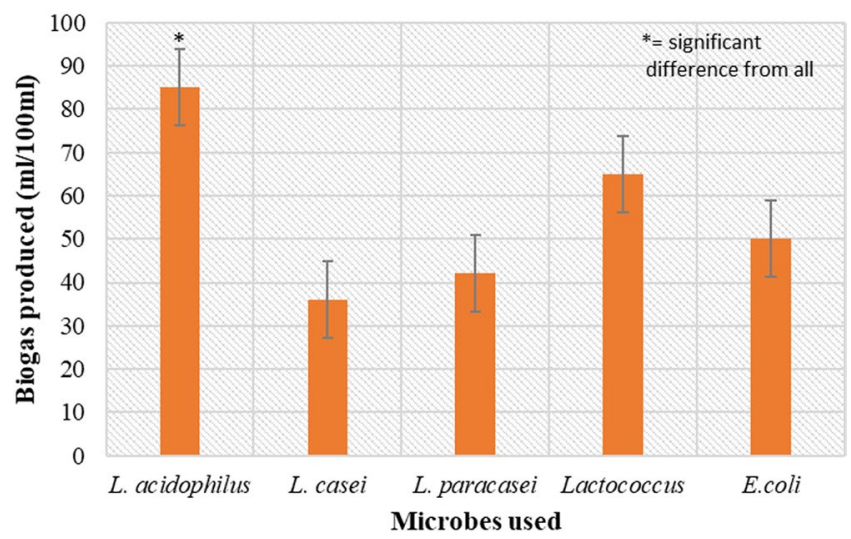

Figure 1. Comparison of biogas production by different bacterial strains in batch mode at $37^{\circ} \mathrm{C}$.

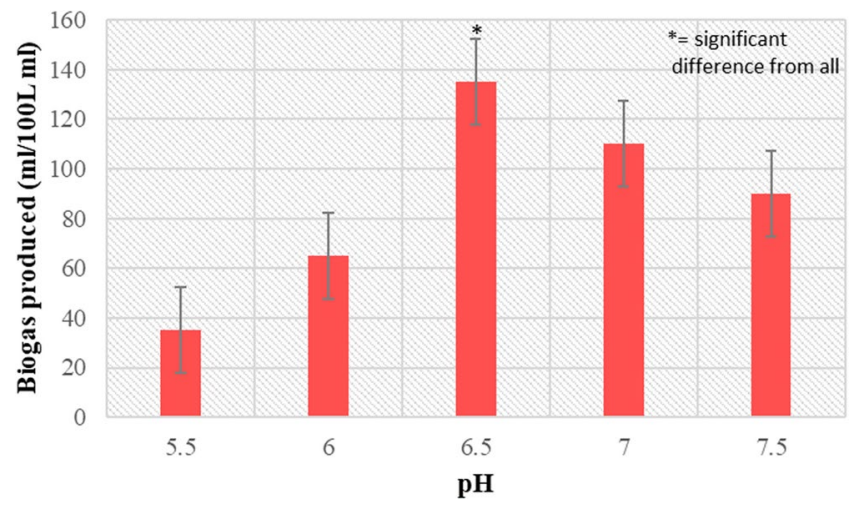

Figure 2. Effect of $\mathrm{pH}(p<0.05)$ on biogas production by food grade bacteria L. acidophilus in the batch mode at $37^{\circ} \mathrm{C}$.

The fermentation effluent collected at different time during experiment were analysed by using HPLC (Shimadzu) fitted with column Animex HPX-87 H (S. N0. 31262 and diameter $300 \times 7.8 \mathrm{~mm}$ ) using $0.018 \mathrm{M}$ $\mathrm{H}_{2} \mathrm{SO}_{4}$ with a flow rate of $0.7 \mathrm{~mL} / \mathrm{min}$ at $65^{\circ} \mathrm{C}$ for 30 minutes.

Statistical analysis. The one way ANOVA was performed to test the significance of the experimental data using Microsoft Excel. During the ANOVA analysis the results of test samples were compared with the control samples and analysed for significance level of $95 \%(p<0.05)$.

\section{Result and Discussion}

Evaluation of food grade bacterial strains for biogas production. The selected strains were analysed for biogas production and the results are represented in Fig. (1). From the data it can be observed that $L$. acidophilus was most efficient in biogas production with a value of $85 \mathrm{~mL} / 100 \mathrm{~mL}$ of culture media used, whereas L. case $i$ was observed to be least efficient with a production value of $36 \mathrm{~mL} / 100 \mathrm{~mL}$. The other three strains used viz. L. paracasei, Lactococcus lactis and E. coli were moderate producers of biogas with production values of $42 \mathrm{~mL} / 100 \mathrm{~mL}, 65 \mathrm{~mL} / 100 \mathrm{~mL}$ and $50 \mathrm{~mL} / 100 \mathrm{~mL}$ respectively. In a study, the waste bread hydrolysate was used as substrate for biohydrogen production by Biohydrogenbacterium R3. The maximum $\mathrm{H}_{2}$ yield of $103 \mathrm{~mL} \mathrm{H}_{2} / \mathrm{g}$ waste bread was observed ${ }^{20}$. In another experiment, effective hydrogen production from food waste hydrolysate in different continuous mixed immobilized sludge reactors (CMISRs) at packing ratios of $10 \%, 15 \%$ and $20 \%$ have been reported. The biohydrogen production at a packing ratio of $15 \%$ was highest with a hydrogen production rate of $353.9 \mathrm{~mL} / \mathrm{h} / \mathrm{L}$ and at high organic loading rate of $40 \mathrm{~kg} / \mathrm{m}^{3} / \mathrm{d}^{21}$. Anaerobic digestion of food waste by using Escherichia cloacae and Enterobacter aerogenes had produced biohydrogen of $155.2 \mathrm{~mL} / \mathrm{g}$ of volatile solids (VS) ${ }^{22}$. In a continuous stirred tank reactor (CSTR) provided with sugarcane, $3.38 \mathrm{mmol} \mathrm{H}_{2} / \mathrm{L} / \mathrm{h}$ hydrogen were produced by using Clostridium butyricum ${ }^{23}$. Configurations including membrane filtration enhanced $\mathrm{H} 2$ yield by over $300 \%$ compared to a more conventional stirred reactor ${ }^{24}$.

Effect of $\mathrm{pH}$ on biogas production. The effect of $\mathrm{pH}$ on biogas production by L. acidophilus is represented in Fig. 2. The biogas production was observed at different starting $\mathrm{pH}$ values of 5.5, 6.0, 6.5, 7.0 and 7.5. From the results it has been observed that the biogas production initially increased up to $\mathrm{pH} 6.5$ with a production value of $135 \mathrm{ml} / 100 \mathrm{ml}$. Above this $\mathrm{pH}$, biogas production started decreasing. Therefore, it can be concluded that $\mathrm{pH}$ 


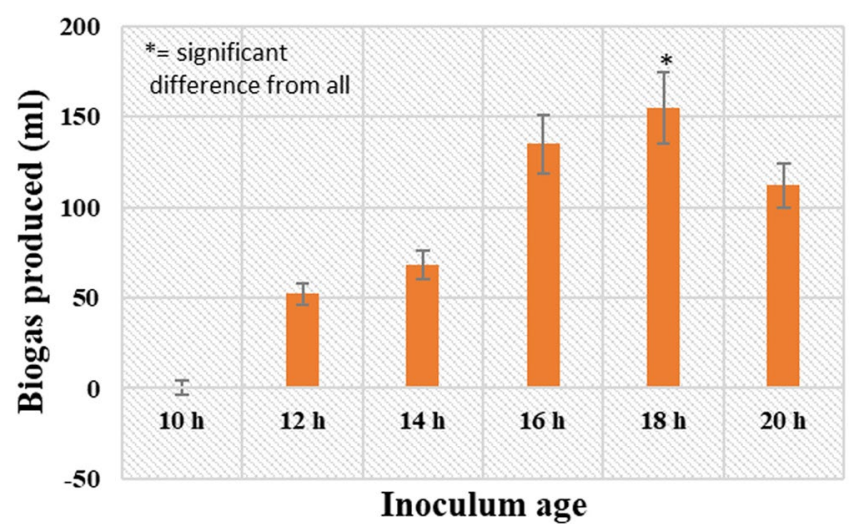

Figure 3. Effect of inoculum age $(p<0.05)$ on biogas production in the batch mode from L. acidophilus at $\mathrm{pH}$ 6.5 and temperature $37^{\circ} \mathrm{C}$.

6.5 is optimal for biogas production under these experimental conditions. By using coconut milk wastewater as the substrate, maximum biogas production i.e. $0.28 \mathrm{~L} \mathrm{H}_{2} / \mathrm{L}$ has been reported at $\mathrm{pH} 6.5$ indicating that such parameter is crucial for dark fermentative hydrogen production ${ }^{25}$. Activity of enzymes varied according to different $\mathrm{pH}$ conditions that become a very important factor for stimulating the biohydrogen producing ability of microrganisms.

Among the studied fermentation $\mathrm{pH}$ values, relatively high biogas yield was observed at $\mathrm{pH} 6.5(135 \mathrm{~mL} /$ $100 \mathrm{~mL})$. Next higher values of biogas produced was observed at $\mathrm{pH} 7.0(110 \mathrm{~mL} / 100 \mathrm{~mL})$, whereas biogas production in fermentation at acidic $\mathrm{pH}$ values decreased more substantially. This decrease in biogas production at lower $\mathrm{pH}$ values can be attributed to decline in the system $\mathrm{pH}$ values below 5.0 due to acid production, that results in shifting of metabolic pathway to solventogenesis from acidogenesis leading to $\mathrm{H}_{2}$ production suppression. The data obtained in this study is in accordance with other reports, showing maximum biogas $/ \mathrm{H}_{2}$ production at $\mathrm{pH}$ values of 6.0 by use of anaerobic mixed microflora ${ }^{26}, \mathrm{pH} 6.5$ by use of sewage microflora ${ }^{25}$. The slight variation in optimum $\mathrm{pH}$ values in different studies can be attributed to change in seed culture composition, inoculum conditions and culture conditions.

Effect of inoculum age and volume. Further the effect of inoculum conditions viz. inoculum age and inoculum volume were investigated. To study the effect of inoculum age the inoculum from cultures incubated for different time intervals were used. Figure 3 represents the effect of inoculum age on biogas production. The results show that initially the biogas production increased with increase in inoculum up to $18 \mathrm{~h}$, attaining a maximum value of $155 \mathrm{ml}$. The next sample was at $20 \mathrm{~h}$, where showed the biogas production decreasing again. Therefore, it can be inferred from the results that $18 \mathrm{~h}$ is the optimum inoculum age for biogas production.

The experiment was performed to examine the inoculum age effect on hydrogen production by using the inoculum grown for $10,12,14,16,18$ and $20 \mathrm{~h}$.

The results showed the strong relationship among inoculum age and healthy growth of the culture alongside $\mathrm{H}_{2}$ production. The inoculum with $18 \mathrm{~h}$ age exhibited the highest percentage of biogas $(155 \mathrm{~mL} / \mathrm{L})$ production. The large retention times might be responsible for the bacterial metabolism to drive in the synthesis of other metabolites such as Poly-Beta-Hydroxybutyrate (PHB) alongside the $\mathrm{H}_{2}$ production ${ }^{27}$. The loss of $\mathrm{H}_{2}$ production activity in batch cultures of $R$. sphaeroides $\mathrm{S}$ was associated with the declined activity of the electron carrier ferredoxin in time dependant manner ${ }^{28,29}$. For PNS bacteria, an inoculum from the exponential growth phase is most suitable for elevated yield of $\mathrm{H}_{2}{ }^{30}$. All the studies are highlighting the effect of inoculum age on different strains with a common conclusion of declined hydrogen yield with increased time span and this study also demonstrates that $\mathrm{H}_{2}$ production by food grade bacteria can be achieved maximum at the inoculum age of $18 \mathrm{~h}$ and lowered with increase in inoculum age.

After that the effect of inoculum volume on biogas production was analysed by varying the volumes of inoculum used, from the results shown in Fig. 4, it can be observed that initially the biogas production increased with increase in inoculum volume and attained a maximum value of $190 \mathrm{~mL}$ at $12.5 \%$ inoculum volume and then further started to decrease in concentration dependent manner with minimum biogas production of $80 \mathrm{~mL}$ at $25 \%$ inoculum volume thus indicating that $12.5 \%$ inoculum volume is optimum for biogas production.

The inoculum volume also plays an imperative role in biogas $/ \mathrm{H}_{2}$ production. $10 \%, 12.5 \%, 15 \%, 20 \%, 25 \%$ were studied as different inoculum volumes. The results exhibit that the most productive inoculum volume was $12.5 \%$ to produce $190 \mathrm{~mL}$ of biogas but at lower and higher inoculum volumes the biogas production decreased. In a study, it has been observed that the $\mathrm{H}_{2}$ yield improved from $2 \mathrm{mmolh}^{-1}$ at $1 \%$ inoculum size to $2.36 \mathrm{mmol} \mathrm{h}^{-1}$ with $10 \%$ inoculum size but the highest yield was achieved with $1 \%$ inoculum ${ }^{31}$ signifies a high substrate to cell ratio would extend the growth phase and provide a longer duration of high rates of $\mathrm{H}_{2}$ production. However, in another study it has been reported that a low substrate (cellulose) to cell density enabled higher $\mathrm{H}_{2}$ yield by using a mixed $\mathrm{H}_{2}$ producing culture ${ }^{32}$. The decline in total gas or $\mathrm{H}_{2}$ at the end of the metabolic process can be credited to the consumption of gas by bacteria as the collected gas was directly in contact with the culture without any trap system. 


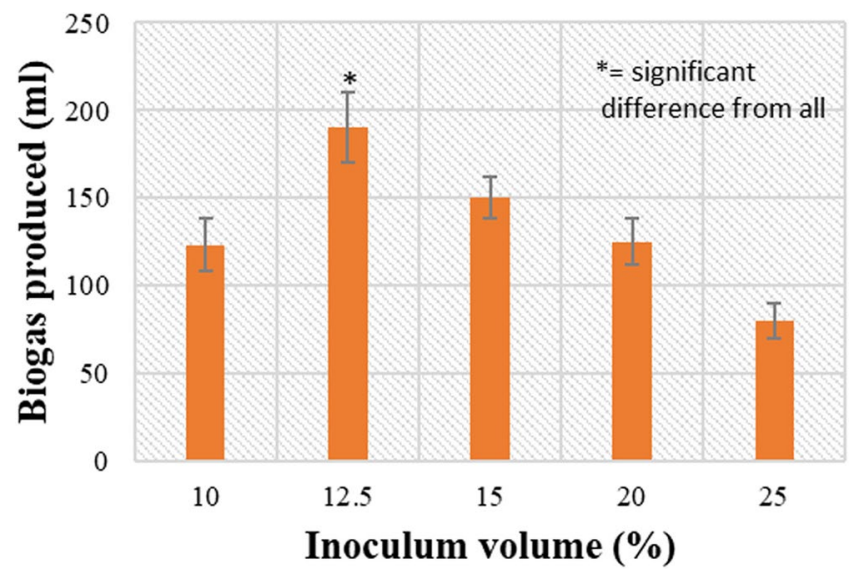

Figure 4. Effect of inoculum volume $(p<0.05)$ on biogas production from L. acidophilus at $\mathrm{pH} 6.5$ and $37^{\circ} \mathrm{C}$ in the batch mode fermentation.

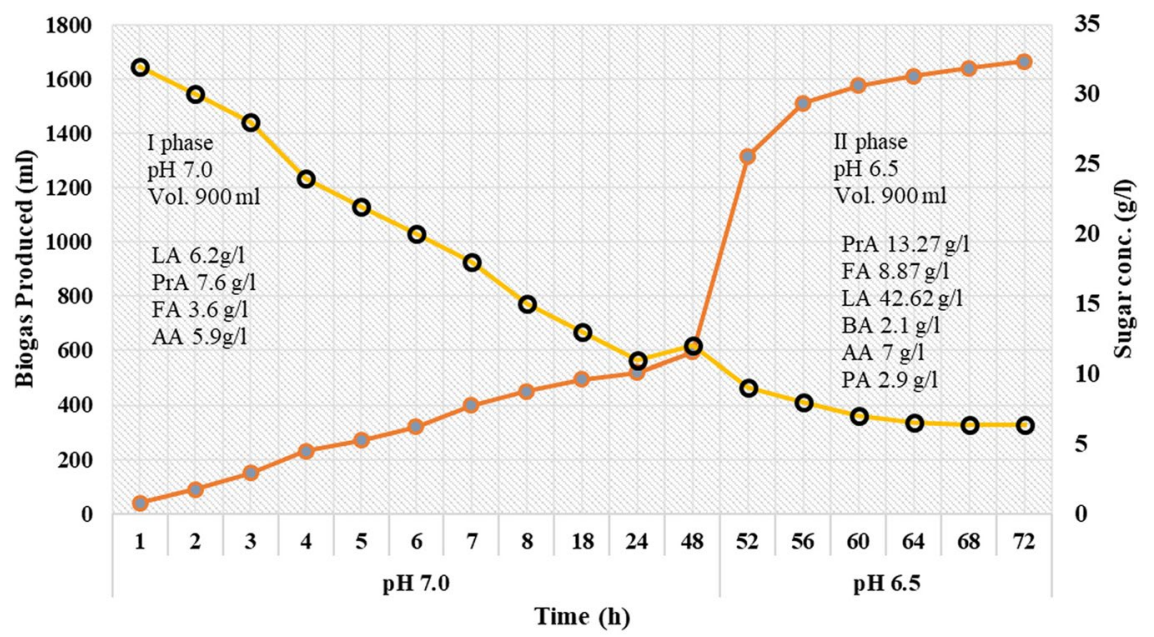

-Biogas produced $(\mathrm{ml}) \quad$ - - Sugar concentration $(\mathrm{g} / \mathrm{l})$

Figure 5. Kinetics of biogas and organic acids production with sugar utilization in 2 phases i.e. phase I ( $\mathrm{pH}$ 7.0) and phase II ( $\mathrm{pH}$ 6.5) from L. acidophilus at $37^{\circ} \mathrm{C}(\mathrm{LA}=$ lactic acid, $\mathrm{BA}=$ butyric acid, $\mathrm{AA}=$ acetic acid, $\mathrm{PA}=$ pyruvic acid, $\mathrm{FA}=$ formic acid, $\operatorname{PrA}=$ propionic acid $)$.

Biogas production in batch fermentation and sugar utilization. The kinetics of biogas production with sugar utilization was observed during the batch fermentation (in two phases, I and II) for $72 \mathrm{~h}$ and the data was plotted between total sugar concentration vs biogas produced. Biogas production was monitored with initial sugar (hexose) concentration being $32 \mathrm{~g} / \mathrm{L}$ at $\mathrm{pH} 7.0$ in phase I (from $0 \mathrm{~h}$ to $48 \mathrm{~h}$ ) with $20 \%$ inoculum ( $18 \mathrm{~h}$ grown). At the start of phase II i.e. $48 \mathrm{~h}$ after start of the experiment, $100 \mathrm{~mL}$ of inoculum $(12.5 \% \mathrm{v} / \mathrm{v})(18 \mathrm{~h}$ grown $)$ was introduced into the spent media $(800 \mathrm{~mL})$ and $\mathrm{pH}$ value was set at 6.5 in the same batch reactor. From the graph (Fig. 5) it can be inferred that at the time of inoculation the total sugar concentration was maximum with a value of $32 \mathrm{~g} / \mathrm{L}$ and then it started declining gradually with increase in biogas production after adjusting the $\mathrm{pH}$ from 7.0 to $\mathrm{pH} 6.5$ in the second phase until completion of the experiment $(72 \mathrm{~h})$. From the graph it can be observed that the biogas production increased with decrease in total sugar concentration.

Biomass concentration. The biomass concentration/cell growth was measured by taking absorbance at $600 \mathrm{~nm}$ after regular intervals of time and graph between time (h) and absorbance was plotted and is represented in Fig. (6). From the plot it can be inferred that the biomass concentration exhibited diauxic pattern that kept on increasing at a lower rate and reached maximum at $48 \mathrm{~h}$ and start growing further in Phase II after the reintroduction of inoculum at $48 \mathrm{~h}$, the biomass concentration reached maximum at $64 \mathrm{~h}$.

Biogas production. The culture was observed for production of biogas from the time of initiation of the experiment and a graph between volume of biogas produced vs time was plotted as represented in Fig. 5. From the graph it can be observed that the biogas produced was minimum with a value of $40 \mathrm{~mL}$ just after the inoculation 


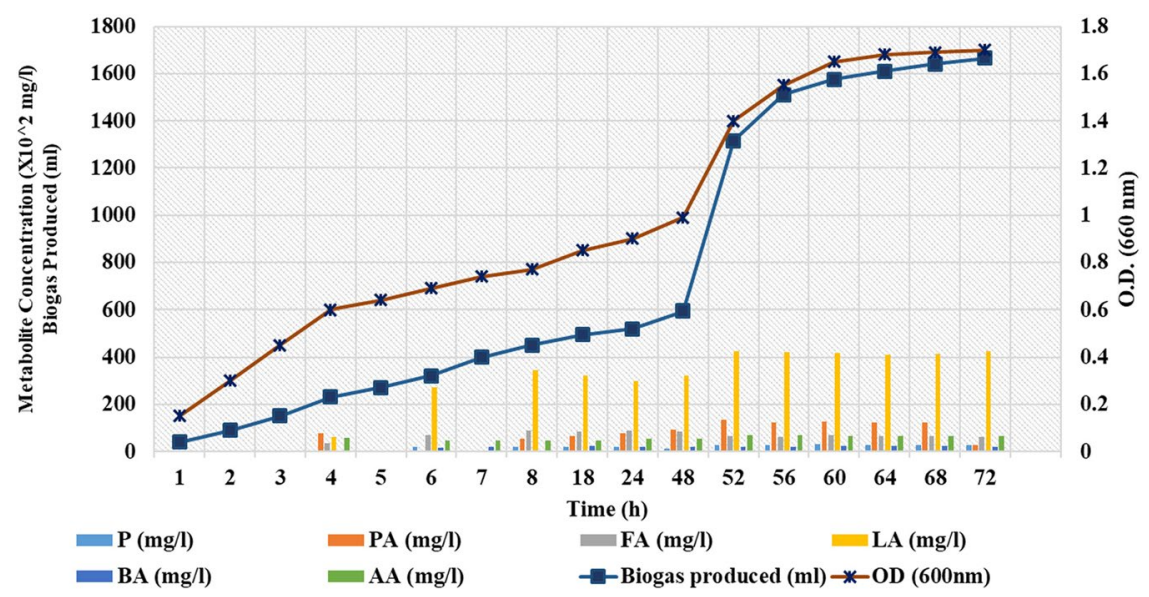

Figure 6. Kinetics of Biogas production $(p<0.05)$ and metabolites $(p<0.05)$ with cell growth during two phases ( $\mathrm{pH} 7.0$ and 6.5) in the batch fermentation at $37^{\circ} \mathrm{C}$ from L. acidophilus.

and then it increased during the bacterial growth and attained a value of $1665 \mathrm{~mL}$ at the end of the phase II indicating that the amount of biogas produced is proportional to the cell biomass concentration in the culture and varies in concentration dependent manner.

Production of end metabolites. The end metabolites produced during bacterial growth which is directly related to the microbial metabolism influencing the fermentation pathways, were analysed for their concentrations using HPLC after sampling at different time intervals under the optimized conditions in batch experiment and metabolite concentrations were plotted against time as represented in Fig. (6). During sugar fermentation by Lactobacillus, the produced metabolites include lactate in homofermentation, lactate, acetate ${ }^{33}$ and propionate ${ }^{34}$ in heterofermentation. The other metabolites detected during the heterofermentation by Lactobacillus bacteria include pyruvate, formate and butyrate ${ }^{35}$ during the biogas production. The amounts of these metabolites varied in different studies owing to experiment conditions viz. inoculum age, inoculum amount, type of substrate used, $\mathrm{pH}$, type of fermentation used ${ }^{33-36}$. In the present study the metabolites produced included pyruvic acid (PA), propionic acid (PrA), formic acid (FA), lactic acid (LA), butyric acid (BA) and acetic acid (AA) having maximum production at $60 \mathrm{~h}, 52 \mathrm{~h}, 24 \mathrm{~h}, 52 \mathrm{~h}, 64 \mathrm{~h}$ and $52 \mathrm{~h}$ respectively along with biogas production. During anaerobic fermentation pyruvate is further oxidized to acetyl-CoA by pyruvate: ferredoxin oxidoreductase (PFOR) complex as represented in the equation below.

$$
\text { Pyruvate }+\mathrm{CoA}+\mathrm{Fd} \rightarrow \text { Acetyl }-\mathrm{CoA}+\mathrm{FdH}+\mathrm{CO}_{2}
$$

Further reduced ferredoxin is also generated in the reaction with NADH, with the reaction being catalysed by $\mathrm{NADH}$ : ferredoxin oxidoreductase (NFOR) as given below.

$$
\mathrm{NADH}+\mathrm{Fd} \rightarrow \mathrm{NAD} D^{+}+\mathrm{FdH}
$$

In this metabolic pathway, hydrogen is released by hydrogenases responsible for catalysing proton reduction utilizing electrons from ferredoxin where the activity of both the involved enzymes is controlled by hydrogen concentration. The hydrogen partial pressure $>60 \mathrm{~Pa}$ are reported to inhibit NFOR activity and result in production of non-gaseous end-products from acetyl-CoA including acetate, butyrate, ethanol, butanol and lactate. Similarly, PFOR is active at hydrogen concentrations lower than $3 \times 10^{4} \mathrm{~Pa}$. The theoretical maximum hydrogen yield during this type of fermentation is 4 ces of hydrogen per mole of hexose utilized. Whereas, during conversion of hexose into butyrate, the hydrogen yield drops to 2 moles per mole of hexose ${ }^{34,35}$. The results obtained in present study are in accordance with the previous reports of metabolite production during sugar fermentation using lactic acid bacteria.

The calculated values of the molar amounts of the end metabolites from the experiment were, AA $(0.12$ moles), PA (0.031 moles), BA (0.01 moles), LA (0.56 moles), FA (0.125 moles) and PrA (0.165 moles) from the 0.114 moles of hexose which are in accordance with the theoretical values. There is an increasing trend for formic acid synthesis as it is clear from graph (6) from $4-8 \mathrm{~h}$ corroborating the significant increase in biogas production through FHL pathway. However, which further increased with time from 8-12 hours. The flux of formic acid remains the same with reduction in lactic acid production where we achieved maximum biogas. However, production rate decreases after 8 hours of fermentation. Results are clearly showing that there is no significant rise after 10 hours of fermentation. However, accumulation of lactic acid increased (32.1\%) from $10 \mathrm{~h}-48 \mathrm{~h}$. From the graph it can be inferred that with time as lactic acid concentration increased, the production of biogas had also increased, which is in accordance with the results previously reported in other studies supporting that lactic acid produced in Phase I inhibited more production of lactic acid and supported more production of biogas in Phase II of fermentation ${ }^{37}$. 


\begin{tabular}{|c|c|c|c|c|}
\hline S. no & Microbes & Wastes & Yield & References \\
\hline 1 & $\begin{array}{l}\text { Thermoanaerobacterium, Caloribacterium, } \\
\text { and Caldanaerobius Species (thermophilic } \\
\text { consortium) }\end{array}$ & $\begin{array}{l}\text { Human waste stimulants, } \\
\text { Wastewater, and Activated sludge }\end{array}$ & $\begin{array}{l}4 \mathrm{mmol} \mathrm{H}_{2} / \mathrm{g} \text { (from human waste), } \\
5.7 \mathrm{mmol} \mathrm{H}_{2} / \mathrm{g} \text { (from waste water), } \\
\text { and } 2.2 \mathrm{mmol} \mathrm{H}_{2} / \mathrm{g} \text { (from activated } \\
\text { sludge) }\end{array}$ & 42 \\
\hline 2 & Rhodobacter capsulatus JP91 & Glucose & $7.8 \mathrm{~mol} \mathrm{H}_{2} / \mathrm{mol}$ glucose & 45 \\
\hline 3 & Mixed culture & Sugar beet & $198 \mathrm{~mL} \mathrm{H}_{2} \mathrm{~g}^{-1} \mathrm{TOC}$ & 47 \\
\hline 4 & $\begin{array}{l}\text { Klebsiella peneumoniae (Inoculum } \\
\text { produced by isolating microorganism } \\
\text { from aviary litter). }\end{array}$ & Brewery waste water & $0.80-1.67 \mathrm{~mol} \mathrm{H}_{2} / \mathrm{mol}$ glucose & 48 \\
\hline 5 & Thermotoga maritima DSM 3109 & Fruit and vegetable wastes & $3.46 \mathrm{~mol} \mathrm{H}_{2} / \mathrm{mol}$ & 49 \\
\hline 6 & $\begin{array}{l}\text { R. capsulatus DSM 1710, R. capsulatus } \\
\text { YO3, R. sphaeroides O.U.001 and Rp. } \\
\text { palustris DSM } 127\end{array}$ & Sugar beet molasses & $\begin{array}{l}12.7 \pm 0.7 \mathrm{~mol} \mathrm{H}_{2} / \mathrm{mol} \text { sucrose } \\
10.6 \pm 0.4 \mathrm{~mol} \mathrm{H}_{2} / \mathrm{mol} \text { sucrose } \\
9.4 \pm 0.5 \mathrm{~mol} \mathrm{H}_{2} / \mathrm{mol} \text { sucrose and } \\
19.0 \pm 0.5 \mathrm{~mol} \mathrm{H}_{2} / \mathrm{mol} \text { sucrose } \\
\text { respectively }\end{array}$ & 50 \\
\hline 7 & Seed sludge & Dairy cow solid waste & $500 \mathrm{~mL} \mathrm{H}_{2} / \mathrm{g}$ total sugar & 40 \\
\hline 8 & Enterobacter aerogenes & Rice straw & $19.7 \mathrm{~mL} \mathrm{H}_{2} / g$ dry rice straw & 51 \\
\hline 9 & Granule sludge & Vinasse & $14.8 \mathrm{~mL} \mathrm{H}_{2} / \mathrm{g} \mathrm{VS}_{\text {substrate }}$ & 52 \\
\hline 10 & Bacillus licheniformis AP1 & Kitchen waste & $17.6 \mathrm{mmol} \mathrm{H}_{2} / \mathrm{g} \mathrm{COD}$ & 53 \\
\hline 11 & Lactobacillus acidophilus & Cheese waste & $\begin{array}{l}1 \mathrm{~mol} \text { of } \mathrm{H}_{2} \text { produced } / \mathrm{mol} \text { of the } \\
\text { hexose }\end{array}$ & This study \\
\hline
\end{tabular}

Table 1. Comparison of hydrogen production found in different studies by using wastes as the substrate.

This finding demonstrated that L. acidophilus can be used for biohydrogen production as well as lactic acid, pyruvic acid, formic acid, acetic acid, butyric acid and propionic acid confirming the mixed acid fermentation under controlled anaerobic environment. Further the molar yield of biohydrogen produced was calculated with a value of $1 \mathrm{~mol}$ of $\mathrm{H}_{2}(67 \%)$ produced/mol of the hexose used. In a study, the maximum hydrogen yield obtained corresponds to $180 \mathrm{~mL} \mathrm{H}_{2} / \mathrm{gVS}$ at $5 \% \mathrm{GLC}$ (glycerol) with the maximum specific production rate value of $13 \mathrm{~mL}$ $\mathrm{H}_{2} /(\text { gVS.h })^{38}$. Different microorganisms yield $\mathrm{H}_{2}$ under specific conditions, such as use of light as energy source by microalgae to split water in production of $\mathrm{H}_{2}$ and cyanobacteria which utilize carbohydrates to store energy from photosynthesis and to produce $\mathrm{H}_{2}$ from water. In various studies different reactor configurations and reaction conditions have been analysed for bio-hydrogen production from food and other organic waste. In a study, waste paper has been utilized for biohydrogen gas production through dark fermentation. The highest amount of hydrogen gas obtained corresponds to $18.9 \mathrm{~g} / \mathrm{L}$ of initial sugar concentration whereas sugar concentrations higher than $18.9 \mathrm{~g} / \mathrm{L}$ resulted in inhibition of product formation ${ }^{39}$.

In another study anaerobic batch fermenter has been used in production of biohydrogen from cow solid waste under the specific hydrolysis conditions. The results exhibited a hydrogen production yield of $97 \mathrm{~mL} \mathrm{H}_{2} / \mathrm{g}$ cow solid waste ${ }^{40}$. In a study where anaerobic fermentation of glucose by Clostridium butyricum yielded $2.02 \mathrm{~mol}$ $\mathrm{H}_{2} /$ mol glucose have been reported ${ }^{13}$. Food waste hydrolysate has been used as a substrate with the production $1.97 \mathrm{~mol} \mathrm{H}_{2} / \mathrm{mol}$ glucose in the batch system ${ }^{2}$. The comparison of biohydrogen produced utilizing various biowastes are shown in Table 1.

Hydrogen production from cheese processing wastewater by using mixed microbial cultures in anaerobic fermentation reached to a value of $10 \mathrm{mM} / \mathrm{gCOD}^{41}$ while using human wastes and activated sludge 2.186 $3.999 \mathrm{mmol} \mathrm{H}_{2} / \mathrm{g}$ of waste has been obtained by thermophilic bacteria ${ }^{42}$. Production of $2.74 \mathrm{~mol} \mathrm{H}_{2} / \mathrm{mol} \mathrm{lactose}$ has been reported by $E$. coli using cheese whey as substrate ${ }^{43}$. In another study by using cheese whey and glucose

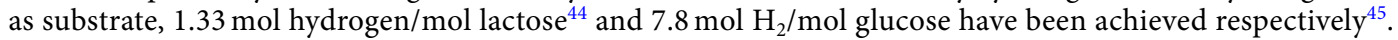
Using cheese whey powder (CWP) $1.03 \mathrm{~mol} \mathrm{H}_{2} / \mathrm{mol}$ glucose has been obtained by thermophilic dark fermentation $^{46}$. From the comparison studies, it can be inferred that biohydrogen produced in our designed experiment using non-pathogenic food grade bacteria with different parameters is within values reported by others.

\section{Conclusion}

In comparison to the lipid, protein and cellulose components, the carbohydrate fraction in food waste plays a significant role in the hydrolysis step during anaerobic degradation. In present study the role of Lactobacillus was observed for biogas production in fed batch reactor using anaerobic fermentation. Among all the bacterial cultures under study, L. acidophilus was observed to have maximum biogas production value. For L. acidophilus, it was observed that under optimized inoculum conditions such as inoculum of $18 \mathrm{~h}$ age, and $12.5 \mathrm{~mL}$ of inoculum per $100 \mathrm{~mL}(12.5 \% \mathrm{v} / \mathrm{v})$ of culture at $\mathrm{pH}$ value of 6.5 , maximum biogas $(1665 \mathrm{~mL})$ was produced after 72 hours of incubation. Along with the biogas other valuable organic acids including pyruvate, propionate, acetate, lactate, formate and butyrate were also produced during anaerobic metabolism. Dark fermentation of food waste for biogas generation exhibits the potential to create an impact on the global energy market for the production of energy from a cheap and renewable carbon source. The isolation of viable and nonpathogenic LAB (lactic acid bacteria) cells for fermentative biogas production from cheese whey indicated that the LAB are capable of surviving in reactor conditions and can influence biogas production. 


\section{References}

1. Rittmann, B. E., Krajmalnik-Brown, R. \& Halden, R. U. Pre-genomic, genomic and post-genomic study of microbial communities involved in bioenergy. Nature reviews microbiology 6(8), 604 (2008).

2. Han, W. et al. Biohydrogen production from enzymatic hydrolysis of food waste in batch and continuous systems. Scientific reports 6, 38395 (2016).

3. Energy Information Administration. Annual energy outlook 2006 with projections to 2030, http://www.scag.ca.gov/rcp/pdf/ publications/1_2006AnnualEnergyOutlook.pdf (2006).

4. Chynoweth, D. P., Owens, J. M. \& Legrand, R. Renewable methane from anaerobic digestion of biomass. Renew. Energy 22, 1-8 (2001).

5. Hall, D. O. \& Rosillo-Calle, F. In Survey of Energy Resources 18th Edn 227-241 (World Energy Council, London, 1998).

6. Logan, B. E. Extracting hydrogen and electricity from renewable resources. Environ. Sci. Technol. 38, 160A-167A (2004).

7. Rittmann, B. E. Opportunities for renewable bioenergy using microorganisms. Biotechnol. Bioeng. 100, 203-212 (2008).

8. Rittmann, B. E., Torres, C. I. \& Kato-Marcus, A. In Emerging Technologies (ed. Shah, V.) (Springer, New York, in the press).

9. Yasin, N. H. M., Mumtaz, T. \& Hassan, M. A. Food waste and food processing waste for biohydrogen production: a review. Journal of environmental management 130, 375-385 (2013).

10. Lin, C. S. K. et al. Food waste as a valuable resource for the production of chemicals, materials and fuels. Current situation and global perspective. Energy \& Environmental Science 6(2), 426-464 (2013).

11. Trzcinski, A. P. Biofuels from food waste: applications of saccharification using fungal solid state fermentation. CRC Press.

12. Kobayashi, T., Xu, K.-Q., Li, Y.-Y. \& Inamori, Y. Evaluation of hydrogen and methane production from municipal solid wastes with different compositions of fat, protein, cellulosic materials and the other carbohydrates. Int J Hydrogen Energy 37, 15711e8 (2012).

13. Jiang, D., Fang, Z., Chin, S. X., Tian, X. F. \& Su, T. C. Biohydrogen production from hydrolysates of selected tropical biomass wastes with Clostridium butyricum. Scientific reports 6, 27205 (2016).

14. JO'M, B. The origin of ideas on a hydrogen economy and its solution to the decay of the environment. International journal of hydrogen energy 27(7-8), 731-740 (2002).

15. Gorman, J. Hydrogen: The next generation: Cleaning up production of a future fuel. Science News 162(15), 235-236 (2002).

16. Bélaich, J. P., Bruschi, M. \& Garcia, J. L. eds. Microbiology and biochemistry of strict anaerobes involved in interspecies hydrogen transfer (Vol. 54). Springer Science \& Business Media (2012).

17. Das, D. \& Veziroğlu, T. N. Hydrogen production by biological processes: a survey of literature. International journal of hydrogen energy 26(1), 13-28 (2001).

18. Chandra, R., Takeuchi, H. \& Hasegawa, T. Methane production from lignocellulosic agricultural crop wastes: A review in context to second generation of biofuel production. Renewable and Sustainable Energy Reviews 16, 1462-1476 (2012).

19. Liu, C. M. et al. Biohydrogen production evaluation from rice straw hydrolysate by concentrated acid pre-treatment in both batch and continuous systems. International Journal of Hydrogen Energy 38, 15823-15829 (2013).

20. Han, W. et al. BioH2 production from waste bread using a two-stage process of enzymatic hydrolysis and dark fermentation. International Journal of Hydrogen Energy 42(50), 29929-29934 (2017).

21. Han, W. et al. Biohydrogen production from food waste hydrolysate using continuous mixed immobilized sludge reactors. Bioresource technology 180, 54-58 (2015).

22. Xiao, L., Deng, Z., Fung, K. Y. \& Ng, K. M. Biohydrogen generation from anaerobic digestion of food waste. International journal of hydrogen energy 38(32), 13907-13913 (2013).

23. Pattra, S., Lay, C. H., Lin, C. Y., Sompong, O. \& Reungsang, A. Performance and population analysis of hydrogen production from sugarcane juice by non-sterile continuous stirred tank reactor augmented with Clostridium butyricum. international journal of hydrogen energy 36(14), 8697-8703 (2011).

24. Zheng, H., Zeng, R. J., Duke, M. C., O’Sullivan, C. A. \& Clarke, W. P. Changes in glucose fermentation pathways by an enriched bacterial culture in response to regulated dissolved H2 concentrations. Biotechnology and bioengineering 112(6), 1177-1186 (2015).

25. Wongthanate, J., Chinnacotpong, K. \& Khumpong, M. Impacts of $\mathrm{pH}$, temperature, and pretreatment method on biohydrogen production from organic wastes by sewage microflora. International Journal of Energy and Environmental Engineering 5(1), 6 (2014).

26. Mohan, S. V. et al. Biohydrogen production from chemical wastewater as substrate by selectively enriched anaerobic mixed consortia: influence of fermentation $\mathrm{pH}$ and substrate composition. International Journal of Hydrogen Energy 32(13), 2286-2295 (2007).

27. Koku, H., Eroglu, I., Gunduz, U., Yucel, M. \& Turker, L. Kinetics of biological hydrogen production by the photosynthetic bacterium Rhodobacter sphaeroides O.U. 001. Int. J. Hydrogen Energy 28, 381-388 (2003).

28. Jee, H., Ohashi, T., Nishizawa, Y. \& Nagai, S. Limiting factor of nitrogenase system mediating Hydrogen production of Rhodobacter sphaeroides S. J. Ferment Technol. 65, 153-158 (1987).

29. Fascetti, E., D’Addario, E., Todini, O. \& Robertiello, A. Photosynthetic hydrogen evolution with volatile organic acid derived from the fermentation of source selected municipal wastes. Int. J. Hydrogen Energy 23, 753-760 (1998).

30. Basak, N. \& Das, D. The prospect of Purple Non-Sulfur (PNS) photosynthetic bacteria for hydrogen production: The present state of the art. World J. Microbiol. Biotechnol. 23, 31-42 (2007).

31. Ferchichi, M., Crabbe, E., Hintz, W., Gil, G. H. \& Almadidy, A. Influence of culture parameters on biological hydrogen production by Clostridium saccharoperbutylacetonicum ATCC 27021. World J. Microbiol. Biotechnol. 21, 855-862 (2005).

32. Lay, J. J. Biohydrogen generation by mesophilic anaerobic fermentation of microcrystalline cellulose. Biotechnol. Bioeng. 74, 280-287 (2001).

33. Kandler, O. Carbohydrate metabolism in lactic acid bacteria. Antonie van Leeuwenhoek 49(3), 209-224 (1983).

34. Gonzalez-Garcia, R. A. et al. Microbial Propionic Acid Production. Fermentation 3(2), 21 (2017).

35. Sikora, A., Błaszczyk, M., Jurkowski, M. \& Zielenkiewicz, U. Lactic acid bacteria in hydrogen-producing consortia: on purpose or by coincidence?. In Lactic acid bacteria-R\&D for food, health and livestock purposes. In Tech (2013).

36. Gomes, B. C., Rosa, P. R. F., Etchebehere, C., Silva, E. L. \& AmâncioVaresche, M. B. Role of homo-and heterofermentative lactic acid bacteria on hydrogen-producing reactors operated with cheese whey wastewater. International Journal of Hydrogen Energy 40(28), 8650-8660 (2015).

37. Kim, T. H., Lee, Y., Chang, K. H. \& Hwang, S. J. Effects of initial lactic acid concentration, HRTs, and OLRs on bio-hydrogen production from lactate-type fermentation. Bioresource technology 103(1), 136-141 (2012).

38. Silva, F. M., Oliveira, L. B., Mahler, C. F. \& Bassin, J. P. Hydrogen production through anaerobic co-digestion of food waste and crude glycerol at mesophilic conditions. International Journal of Hydrogen Energy 42(36), 22720-22729 (2017).

39. Eker, S. \& Sarp, M. Hydrogen gas production from waste paper by dark fermentation: Effects of initial substrate and biomass concentrations. International Journal of Hydrogen Energy 42(4), 2562-2568 (2017).

40. Chu, C. Y. \& Wang, Z. F. Dairy cow solid waste hydrolysis and hydrogen/methane productions by anaerobic digestion technology. International Journal of Hydrogen Energy 42(52), 30591-30598 (2017).

41. Yang, P., Zhang, R., McGarvey, J. A. \& Benemann, J. R. Biohydrogen production from cheese processing wastewater by anaerobic fermentation using mixed microbial communities. International Journal of Hydrogen Energy 32(18), 4761-4771 (2007).

42. Wang, J. et al. Biohydrogen production from space crew's waste simulants using thermophilic consolidated bioprocessing. Bioresource technology 255, 349-353 (2018). 
43. Rosales-Colunga, L. M., Razo-Flores, E., Ordoñez, L. G., Alatriste-Mondragón, F. \& De León-Rodríguez, A. Hydrogen production by Escherichia coli $\Delta$ hycA $\Delta$ lacI using cheese whey as substrate. international journal of hydrogen energy 35(2), 491-499 (2010).

44. Rosa, P. R. F., Santos, S. C., Sakamoto, I. K., Varesche, M. B. A. \& Silva, E. L. Hydrogen production from cheese whey with ethanoltype fermentation: effect of hydraulic retention time on the microbial community composition. Bioresource technology 161, 10-19 (2014).

45. Sağı̆, E., Yucel, M. \& Hallenbeck, P. C. Demonstration and optimization of sequential microaerobic dark-and photo-fermentation biohydrogen production by immobilized Rhodobacter capsulatus JP91. Bioresource technology 250, 43-52 (2018).

46. Kargi, F., Eren, N. S. \& Ozmihci, S. Hydrogen gas production from cheese whey powder (CWP) solution by thermophilic dark fermentation. International journal of hydrogen energy 37(3), 2260-2266 (2012).

47. Eker, S. and Erkul, B. Biohydrogen production by extracted fermentation from sugar beet. International Journal of Hydrogen Energy (2018).

48. Estevam, A. et al. Production of biohydrogen from brewery wastewater using Klebsiella pneumoniae isolated from the environment. International Journal of Hydrogen Energy 43(9), 4276-4283 (2018).

49. Saidi, R. et al. Biohydrogen production from hyperthermophilic anaerobic digestion of fruit and vegetable wastes in seawater: Simplification of the culture medium of Thermotoga maritima. Waste Management 71, 474-484 (2018).

50. Sagir, E., Ozgur, E., Gunduz, U., Eroglu, I. \& Yucel, M. Single-stage photofermentative biohydrogen production from sugar beet molasses by different purple non-sulfur bacteria. Bioprocess and biosystems engineering 40(11), 1589-1601 (2017).

51. Asadi, N. \& Zilouei, H. Optimization of organosolv pretreatment of rice straw for enhanced biohydrogen production using Enterobacter aerogenes. Bioresource technology 227, 335-344 (2017).

52. Fu, S. F., Xu, X. H., Dai, M., Yuan, X. Z. \& Guo, R. B. Hydrogen and methane production from vinasse using two-stage anaerobic digestion. Process Safety and Environmental Protection 107, 81-86 (2017).

53. Srivastava, S., Kumar, A., Pandey, A. \& Pandey, A. Intensification of hydrogen production by B. licheniformis using kitchen waste as substrate. International Journal of Hydrogen Energy 42(34), 21659-21666 (2017).

\section{Acknowledgements}

Prof. Anjana Pandey is thankful to Australian Government for the award of Executive Endeavour Fellowship 2015. She acknowledges the Director, Prof. Stephen Grey of ISI, Melbourne for supporting this programme. Ms. Stacey Lloyd, Ms. Sarah Fraser and Mr. Joseph Pelle are also acknowledged for providing administrative and technical help.

\section{Author Contributions}

The present work has been designed and conducted by Dr. Anjana Pandey. Ms. Saumya Srivastava and Ms. Priya Rai contributed in manuscript preparation and Prof. Mikel Duke contributed in critical examination of the manuscript.

\section{Additional Information}

Competing Interests: The authors declare no competing interests.

Publisher's note: Springer Nature remains neutral with regard to jurisdictional claims in published maps and institutional affiliations.

(c) Open Access This article is licensed under a Creative Commons Attribution 4.0 International

License, which permits use, sharing, adaptation, distribution and reproduction in any medium or format, as long as you give appropriate credit to the original author(s) and the source, provide a link to the Creative Commons license, and indicate if changes were made. The images or other third party material in this article are included in the article's Creative Commons license, unless indicated otherwise in a credit line to the material. If material is not included in the article's Creative Commons license and your intended use is not permitted by statutory regulation or exceeds the permitted use, you will need to obtain permission directly from the copyright holder. To view a copy of this license, visit http://creativecommons.org/licenses/by/4.0/.

(c) The Author(s) 2019 